\title{
ANALISIS KEPUASAN PASIEN GANCANG ARON DENGAN METODE IMPORTANCE PERFORMANCE ANALYSIS DI RSUD BLAMBANGAN
}

\author{
Yuliavira Sudhasni*, Christyana Sandra, Yennike Tri Herawati \\ Fakultas Kesehatan Masyarakat, Universitas Jember, Jember, Indonesia \\ email: csandra@unej.ac.id
}

\begin{abstract}
Abstrak
Gancang Aron (Gugus Antisipasi Cegah Antrian Panjang dengan Antar Obat ke Rumah Pasien) merupakan program inovasi RSUD Blambangan untuk mengurangi waktu tunggu pelayanan obat. Penelitian ini bertujuan untuk menganalisis tingkat kepuasan pasien pengguna program Gancang Aron dengan metode Importance Performance Analysis di RSUD Blambangan Kabupaten Banyuwangi. Penelitian ini merupakan penelitian deskriptif dengan pendekatan kuantitatif. Jumlah sampel sebanyak 96 responden yang ditentukan dengan teknik simple random sampling. Hasil penelitian menunjukkan bahwa sebagian besar atribut dianggap penting namun kinerjanya masih ada yang dianggap kurang baik dan belum memenuhi harapan, yaitu petugas kurang tepat waktu dalam melayani pasien, petugas kurang menerima dan mendengarkan keluhan pasien dengan baik, instalasi farmasi memiliki persediaan obat yang kurang lengkap, dan ruang tunggu kurang memadai. Tingkat kepuasan pasien pengguna program Gancang Aron ditinjau dari dimensi kompetensi teknis, akses terhadap pelayanan, kelangsungan pelayanan, keamanan, efektivitas, hubungan antar manusia, dan efisiensi ialah sangat puas, sedangkan ditinjau dari dimensi kenyamanan ialah puas, namun atribut ruang tunggu memadai dan tersedianya AC/televisi/majalah di ruang tunggu belum memenuhi harapan pasien. Berdasarkan diagram kartesius diketahui bahwa atribut tersebar dalam empat kuadran. Atribut yang dianggap penting dan telah baik kinerjanya sebanyak 7 atribut, sedangkan atribut yang dianggap kurang penting dan belum baik kinerjanya sebanyak 8 atribut.
\end{abstract}

Kata kunci: diagram kartesius, gancang aron, kepuasan pasien

\begin{abstract}
Gancang Aron (Anticipation Group to Prevent Long Queues by Delivering Medicines to Patients' Homes) is an innovation program at the Blambangan Hospital to reduce waiting time for drug services. This study aims to analyze the level of patient satisfaction using the Gancang Aron program using the Importance Performance Analysis method at Blambangan Hospital, Banyuwangi Regency. This research is a descriptive research with a quantitative approach. The number of samples as many as 96 respondents determined by simple random sampling technique. The results showed that most of the attributes were considered important but their performance was still considered unfavorable and did not meet expectations, namely officers were less punctual in serving patients, officers did not receive and listen to patient complaints properly, pharmacy installations have inadequate drug supplies, and inadequate waiting rooms. The level of patient satisfaction using the Gancang Aron program in terms of the dimensions of technical competence, access to services, service continuity, security, effectiveness, human relations, and efficiency is very satisfied, while in terms of the comfort dimension it is satisfied, but the attributes of the waiting room are adequate and the availability of air conditioning/television/magazines in the waiting room have not met the patient's expectations. Based on the cartesian diagram, it is known that the attributes are spread in four quadrants. Attributes that are considered important and have good performance are 7 attributes, while attributes that are considered less important and have not performed well are 8 attributes.
\end{abstract}

Keywords: cartesian diagram, gancang aron, patient satisfaction

\section{PENDAHULUAN}

Kesehatan merupakan salah satu kebutuhan manusia yang mutlak diperlukan untuk kelangsungan hidup, sehingga saat ini banyak dijumpai fasilitas layanan kesehatan, seperti rumah sakit. Rumah sakit ialah institusi yang dilakukan oleh tenaga medis 
profesional yang terstruktur (Supartiningsih, 2017). Rumah sakit sebagai provider pelayanan kesehatan harus mampu bersaing dengan provider pelayanan kesehatan lainnya agar dapat survive. Persaingan yang semakin ketat ini menuntut provider pelayanan kesehatan untuk meningkatkan kualitas pelayanan agar tercipta kepuasan pasien (Gunawan, 2013). Kualitas pelayanan memegang peranan penting dalam mewujudkan kepuasan pasien (Mustika, 2019).

Kualitas pelayanan kesehatan dan kepuasan pasien tidak dapat dipisahkan karena saling berpengaruh dan berkaitan (Pasalli', 2021), serta menjadi indikator keberhasilan penyelenggaraan layanan di rumah sakit (Suratri, 2018). Suatu layanan kesehatan dikatakan bermutu jika kepuasan bagi pasien dapat terwujud (Sesrianty, 2019). Pasien akan puas apabila mendapatkan pelayanan yang dapat memenuhi semua kebutuhan dan keinginannya. Salah satunya adalah layanan kefarmasian yang berupa kecepatan pelayanan kefarmasian dan komunikasi yang dilakukan antara tenaga kefarmasian dengan pasien pada saat pelayanan kefarmasian berlangsung (Megawati, 2017).

Pelayanan farmasi tidak dapat dipandang sebelah mata, karena pelayanan kesehatan tanpa farmasi di rumah sakit akan kurang lengkap. Pelayanan farmasi ialah bagian dari aktivitas dalam rumah sakit yang menyokong kualitas layanan kesehatan. Pernyataan tersebut dijelaskan dalam Permenkes RI Nomor 72 Tahun 2016 tentang Standar Pelayanan Kefarmasian di Rumah Sakit, yang menjelaskan bahwa pelayanan kefarmasian di rumah sakit adalah unit yang tak dapat dipisahkan dari sistem layanan kesehatan rumah sakit yang mengarah pada pelayanan pasien, penyediaan Bahan Medis Habis Pakai (BMHP), alat kesehatan, dan sediaan farmasi yang berkualitas serta terjangkau bagi seluruh masyarakat.

Hasil dari beberapa penelitian menunjukkan bahwa waktu tunggu pelayanan resep masih lama atau belum sesuai standar pelayanan minimal yang ditetapkan oleh kementerian kesehatan yaitu > 60 menit (Bustani, 2015). Menurut penelitian yang dilakukan oleh (Esti et al., 2013), waktu tunggu pelayanan obat termasuk faktor yang berpengaruh terhadap kepuasan pasien. Kepuasan pasien dipengaruhi oleh 2 faktor, yaitu faktor internal dan faktor eksternal. Dimensi mutu pelayanan merupakan salah satu faktor eksternal yang dapat mempengaruhi kepuasan pasien. Dimensi mutu pelayanan merupakan hal penting yang perlu diukur dibanding dengan faktor eksternal lainnya. Hal ini dikarenakan berbagai faktor tersebut telah tercantum dalam variabel dimensi mutu pelayanan yang terdiri dari dimensi kompetensi teknis, akses terhadap pelayanan, efektivitas, hubungan antar manusia, efisiensi, kelangsungan pelayanan, keamanan, dan kenyamanan.

Terdapat salah satu rumah sakit yang menerapkan program inovasi untuk mengurangi waktu tunggu pelayanan obat yaitu RSUD Blambangan, Kabupaten Banyuwangi. Program tersebut adalah program Gancang Aron (Gugus Antisipasi Cegah Antrian Panjang dengan Antar Obat ke Rumah Pasien). Gancang Aron berasal dari Bahasa Osing yang artinya lekas sembuh. Inovasi Gancang Aron sudah diapresiasi positif oleh masyarakat umum, pasien dan keluarganya, serta oleh pemerintah nasional dengan diberikannya penghargaan di dalam Top 44 Sistem Informasi Inovasi Pelayanan Publik (Sinovik) yang digagas oleh Kementerian Pendayagunaan Aparatur Negara dan Reformasi Birokrasi (KemenPAN dan RB) tahun 2018 (Asmara, 2019). Pengantaran obat pada program ini dilakukan oleh apoteker rumah sakit dan bermitra dengan gojek. Faktor yang melatarbelakangi terbentuknya program ini adalah adanya keluhan utama pasien selama tiga tahun berturut-turut pada tahun 2014-2016 dengan persentase tahun 2014 sebesar 28\%, tahun 2015 sebesar 26\%, dan tahun 2016 sebesar $29 \%$. Keluhan tersebut berdasarkan waktu tunggu pelayanan obat di RSUD Blambangan yang cukup lama dan belum memenuhi standar pelayanan farmasi.

Selain itu, pada tahun 2013-2016 capaian kepuasan masyarakat terhadap pelayanan yang diberikan di RSUD Blambangan mengalami penurunan. Tahun 2013 sebesar 80,15, tahun 2014 sebesar 76,70, tahun 2015 sebesar 75,31, dan tahun 2016 sebesar 74,26 (Profil RSUD Blambangan Banyuwangi tahun 2017 dalam (Widyanti, 2018). Pada tahun 2017, capaian kepuasan masyarakat 
pada pelayanan farmasi menduduki posisi capaian terendah di RSUD Blambangan yakni sebesar 71,4\%, hal ini belum memenuhi SPM kepuasan pelanggan $\geq 80 \%$ (Widyanti, 2018).

Berdasarkan hasil penelitian (Widyanti, 2018), pada pelaksanaan program Gancang Aron ini terdapat keluhan pada pasien yaitu pernah terjadi kesalahan pada saat pengantaran obat sebesar $32,8 \%$. Kesalahan ini berupa resep berbeda dengan obat, jumlah obat kurang dari jumlah obat yang ada di resep, dan kesalahan pengiriman obat saat driver salah mengambil obat pasien di depo delivery yang sebenarnya bukan driver tersebut yang mengantarkan obat tersebut. Keluhan lain yang dialami pasien yaitu pengantaran obat yang lama sebesar $21,6 \%$. Pengantaran obat lama terjadi saat obat yang masuk banyak dan Sumber Daya Manusia (SDM) yang ada tidak mampu mengerjakan proses penyiapan obat dengan cepat, sehingga proses pengerjaannya lama.

Selain itu, berdasarkan hasil penelitian (Widyanti, 2018), sebesar 66,7\% manajemen instalasi farmasi menyatakan bahwa tidak ada batasan waktu minimal pengantaran obat kepada pasien yang ada di rumah, sehingga untuk mengetahui rata-rata waktu obat sampai pada pasien juga tidak diketahui. Serta sebesar $72,2 \%$ manajemen instalasi farmasi menyatakan bahwa tidak ada perhitungan waktu tunggu sesuai Standar Pelayanan Minimal (SPM) pelayanan farmasi terkait pengantaran obat kepada pasien yang ada di rumah.

Hasil studi pendahuluan menunjukkan bahwa 6 orang pasien atau sebesar 30\% pasien pernah mengalami keluhan pada saat menggunakan program Gancang Aron, 1 orang pasien atau sebesar 5\% pasien merasa terganggu dengan adanya keluhan yang pernah dialami tersebut, 5 orang pasien atau sebesar $25 \%$ pasien pernah menerima obat dengan jumlah yang tidak sesuai dengan resep, 6 orang pasien atau sebesar 30\% pasien pernah mengalami keluhan waktu pengantaran obat yang lama, dan 13 orang pasien atau sebesar $65 \%$ pasien menyatakan bahwa tidak terdapat komunikasi dengan petugas pengantar. Selain itu, dalam pelayanan Gancang Aron belum ada standar pelayanan minimal terkait waktu pengantaran atau berapa lama obat tersebut sampai di rumah pasien dari pasien menyerahkan resep, sehingga pasien tidak tenang menunggu obat di rumah, mau sholat ataupun tidur istirahat namun takut nanti obat akan datang karena mereka tidak mengetahui obat datang jam berapa.

Setiap rumah sakit perlu melakukan pengukuran kepuasan pasien, baik kepuasan fungsional maupun kepuasan psikologikal secara berkala karena masyarakat semakin kritis dan semakin menuntut pelayanan yang berkualitas. Tingkat kepuasan dapat dikatakan sebagai fungsi dari adanya perbedaan antara harapan dengan kinerja yang didapatkan (Astuti, 2014). Pengukuran kepuasan pasien dapat dilakukan dengan metode Importance Performance Analysis (IPA) yang ditampilkan dalam bentuk diagram kartesius. Metode IPA telah digunakan pada berbagai bidang kajian, hal ini dikarenakan penerapan metode IPA yang mudah dan tampilan hasil analisis yang memberikan kemudahan untuk melakukan usulan perbaikan kinerja (Winarno, 2017).

Metode IPA mempunyai kelebihan dibanding dengan metode lain yakni menunjukkan atribut produk/jasa yang perlu ditingkatkan ataupun dikurangi untuk menjaga kepuasan konsumen, hasil relatif mudah diinterpretasikan, skala relatif mudah dimengerti dan memerlukan biaya yang rendah (Ujiati, 2017). Metode IPA berguna untuk mengukur tingkat kepuasan pasien dengan menggunakan skor kinerja dan skor kepentingan. Penelitian yang dilakukan di RSUD Blambangan ini menggunakan metode IPA karena metode ini menampilkan informasi mengenai atribut apa yang menurut pasien pengguna program Gancang Aron masih kurang memuaskan dan menimbulkan keluhan, sehingga dengan informasi ini pihak RSUD Blambangan dapat melakukan usulan perbaikan mengenai atribut yang belum memuaskan untuk meningkatkan kualitas pelayanan program Gancang Aron.

Penelitian ini bertujuan untuk menganalisis tingkat kepuasan pasien pengguna program Gancang Aron dengan metode Importance Performance Analysis di RSUD Blambangan Kabupaten Banyuwangi.

\section{METODE PENELITIAN}

Penelitian ini merupakan jenis penelitian deskriptif dengan pendekatan kuantitatif. 
Penelitian dilakukan di instalasi farmasi RSUD Blambangan Kabupaten Banyuwangi pada bulan Februari-April 2021 dan telah mendapatkan persetujuan etik dengan nomor 1140/UN25.8/KEPK/DL/2021. Populasi pada penelitian ini yaitu semua pasien rawat jalan pengguna program Gancang Aron pada tahun 2020 yang berjumlah 809 pasien. Sampel dalam penelitian ini ialah 96 responden yang dipilih dengan metode simple random sampling. Pengumpulan data dilakukan dengan studi dokumentasi dan wawancara kepada responden dengan menggunakan bantuan kuesioner. Analisis data pada penelitian ini ialah analisis univariat (analisis deskriptif). Analisis univariat berguna untuk mendapatkan gambaran distribusi frekuensi dan persentase dari variabel yang diteliti (Rivaldi, 2019).

Kuesioner kepuasan telah dilakukan uji validitas dan reliabilitas dengan menggunakan SPSS. Kuesioner diujikan kepada 20 pasien pengguna layanan antar obat di RSUD Genteng Kabupaten Banyuwangi. Teknik korelasi yang digunakan untuk uji validitas yaitu teknik korelasi Product Moment dengan keputusan $r$ hitung $>r$ tabel maka valid dan apabila $\mathrm{r}$ hitung $<\mathrm{r}$ tabel maka tidak valid (Sugiyono, 2015). Hasil uji validitas menunjukkan bahwa seluruh pernyataan dapat dikatakan valid. Uji reliabilitas menggunakan Cronbach's Alpha dengan keputusan uji apabila Cronbach's Alpha $>0,60$ maka reliabel, sedangkan apabila Cronbach's Alpha $<0,60$ maka tidak reliabel (Hastono, 2016). Hasil uji reliabilitas menunjukkan bahwa seluruh pernyataan dapat dikatakan reliabel.

\section{HASIL DAN PEMBAHASAN}

\section{Skor Kinerja dan Skor Kepentingan Setiap Atribut Perhitungan Skor Kinerja}

Pada kinerja, setiap atribut diskorkan kemudian dijumlahkan dan dirata-rata. Perhitungan skor kinerja setiap atribut ditunjukkan pada tabel 1. Pada tabel 1 tersebut, atribut A merupakan kompetensi teknis, atribut $\mathrm{B}$ merupakan akses terhadap pelayanan, atribut $\mathrm{C}$ merupakan efektivitas, atribut D merupakan hubungan antar manusia, atribut $\mathrm{E}$ merupakan efisiensi, atribut $\mathrm{F}$ merupakan kelangsungan pelayanan, atribut $\mathrm{G}$ merupakan keamanan, dan atribut $\mathrm{H}$ merupakan kenyamanan.

Tabel 1. Perhitungan Skor Kinerja

\begin{tabular}{|c|c|c|c|}
\hline No. & Atribut & $\begin{array}{c}\text { Total Skor } \\
\text { Atribut } \\
\text { Kinerja }\end{array}$ & $\begin{array}{c}\text { Rata-Rata } \\
\text { Skor } \\
\text { Atribut } \\
\text { Kinerja }\end{array}$ \\
\hline 1. & A1 & 306 & 3,19 \\
\hline 2. & $\mathrm{~A} 2$ & 303 & 3,16 \\
\hline 3. & A3 & 299 & 3,11 \\
\hline 4. & A4 & 305 & 3,18 \\
\hline 5. & B1 & 314 & 3,27 \\
\hline 6. & B2 & 318 & 3,31 \\
\hline 7. & B3 & 300 & 3,13 \\
\hline 8. & B4 & 304 & 3,17 \\
\hline 9. & $\mathrm{C} 1$ & 302 & 3,15 \\
\hline 10. & $\mathrm{C} 2$ & 287 & 2,99 \\
\hline 11. & D1 & 308 & 3,21 \\
\hline 12. & D2 & 295 & 3,07 \\
\hline 13. & D3 & 293 & 3,05 \\
\hline 14. & D4 & 297 & 3,09 \\
\hline 15. & E1 & 291 & 3,03 \\
\hline 16. & E2 & 299 & 3,11 \\
\hline 17. & E3 & 290 & 3,02 \\
\hline 18. & $\mathrm{~F} 1$ & 322 & 3,35 \\
\hline 19. & $\mathrm{~F} 2$ & 299 & 3,11 \\
\hline 20. & $\mathrm{~F} 3$ & 314 & 3,27 \\
\hline 21. & G1 & 298 & 3,10 \\
\hline 22. & $\mathrm{G} 2$ & 313 & 3,26 \\
\hline 23. & G3 & 290 & 3,02 \\
\hline 24. & G4 & 317 & 3,30 \\
\hline 25. & $\mathrm{H} 1$ & 299 & 3,11 \\
\hline 26. & $\mathrm{H} 2$ & 271 & 2,82 \\
\hline 27. & H3 & 249 & 2,59 \\
\hline \multirow[t]{2}{*}{28.} & $\mathrm{H} 4$ & 292 & 3,04 \\
\hline & Total & 8.375 & 87,24 \\
\hline \multicolumn{3}{|c|}{ Rata-Rata Skor Kinerja } & 3,12 \\
\hline
\end{tabular}

Berdasarkan tabel 1 diketahui bahwa terdapat 13 atribut yang dianggap memadai atau kinerjanya baik oleh responden yang ditunjukkan dengan penilaian rata-rata skor atribut berada diatas rata-rata skor kinerja. Dari hasil perhitungan, rata-rata skor kinerja adalah 3,12 .

\section{Perhitungan Skor Kepentingan}

Pada kepentingan, setiap atribut diskorkan kemudian dijumlahkan dan diratarata. Perhitungan skor kepentingan setiap atribut ditunjukkan pada tabel 2. Pada tabel 2 
tersebut, atribut A merupakan kompetensi teknis, atribut B merupakan akses terhadap pelayanan, atribut $\mathrm{C}$ merupakan efektivitas, atribut $\mathrm{D}$ merupakan hubungan antar manusia, atribut $\mathrm{E}$ merupakan efisiensi, atribut $\mathrm{F}$ merupakan kelangsungan pelayanan, atribut $\mathrm{G}$ merupakan keamanan, dan atribut $\mathrm{H}$ merupakan kenyamanan.

Tabel 2. Perhitungan Skor Kepentingan

\begin{tabular}{cccc}
\hline No. & Atribut & $\begin{array}{c}\text { Total Skor } \\
\text { Atribut } \\
\text { Kepentingan }\end{array}$ & $\begin{array}{c}\text { Rata-Rata } \\
\text { Skor Atribut } \\
\text { Kepentingan }\end{array}$ \\
\hline 1. & A1 & 357 & 3,72 \\
2. & A2 & 345 & 3,59 \\
3. & A3 & 345 & 3,59 \\
4. & A4 & 353 & 3,68 \\
5. & B1 & 357 & 3,72 \\
6. & B2 & 349 & 3,64 \\
7. & B3 & 351 & 3,66 \\
8. & B4 & 359 & 3,74 \\
9. & C1 & 353 & 3,68 \\
10. & C2 & 365 & 3,80 \\
11. & D1 & 361 & 3,76 \\
12. & D2 & 369 & 3,84 \\
13. & D3 & 355 & 3,70 \\
14. & D4 & 359 & 3,74 \\
15. & E1 & 345 & 3,59 \\
16. & E2 & 374 & 3,90 \\
17. & E3 & 338 & 3,52
\end{tabular}

\begin{tabular}{|c|c|c|c|}
\hline 18. & F1 & 338 & 3,52 \\
\hline 19. & F2 & 346 & 3,60 \\
\hline 20. & F3 & 348 & 3,62 \\
\hline 21. & G1 & 347 & 3,61 \\
\hline 22. & G2 & 357 & 3,72 \\
\hline 23. & G3 & 348 & 3,62 \\
\hline 24. & G4 & 362 & 3,77 \\
\hline 25. & H1 & 361 & 3,76 \\
\hline 26. & $\mathrm{H} 2$ & 357 & 3,72 \\
\hline 27. & H3 & 328 & 3,42 \\
\hline \multirow[t]{2}{*}{28.} & $\mathrm{H} 4$ & 351 & 3,66 \\
\hline & Total & 9.878 & 102,89 \\
\hline
\end{tabular}

Berdasarkan tabel 2 diketahui bahwa terdapat 15 atribut yang dianggap penting atau diharapkan oleh responden yang ditunjukkan dengan penilaian rata-rata skor atribut berada diatas rata-rata skor kepentingan. Dari hasil perhitungan, ratarata skor kepentingan adalah 3,67.

\section{Skor Tingkat Kepuasan Pasien Pengguna Program Gancang Aron Ditinjau dari Dimensi Kompetensi Teknis}

Dimensi kompetensi teknis dalam proses pelayanan mencakup ketrampilan, kemampuan, dan penampilan petugas (Wanarto, 2013).

Tabel 3. Rata-rata Tingkat Kepuasan Pasien Pengguna Program Gancang Aron Berdasarkan Dimensi Kompetensi Teknis

\begin{tabular}{clcccc}
\hline No. & \multicolumn{1}{c}{ Pernyataan } & Kinerja & Kepentingan & Nilai Kepuasan & Kategori \\
\hline 1. & $\begin{array}{l}\text { Petugas terampil dalam melayani } \\
\text { pasien }\end{array}$ & 3,19 & 3,72 & $85,75 \%$ & Sangat puas \\
2. & Petugas berpenampilan rapi & 3,16 & 3,59 & $88,02 \%$ & Sangat puas \\
3. $\begin{array}{l}\text { Pelaksanaan pelayanan program } \\
\text { Gancang Aron sesuai dengan } \\
\text { prosedur }\end{array}$ & 3,11 & 3,59 & $86,63 \%$ & Sangat puas \\
$\begin{array}{l}\text { Kesesuaian etiket/label yang } \\
\text { tertera pada obat dengan } \\
\text { penjelasan petugas }\end{array}$ & 3,18 & 3,68 & $86,41 \%$ & Sangat puas \\
\hline$\quad$ Rata-rata & 3,16 & 3,65 & $86,70 \%$ & Sangat puas \\
\hline
\end{tabular}

Berdasarkan hasil penelitian yang disajikan dalam tabel 3 menunjukkan bahwa tingkat kepuasan pasien pengguna program Gancang Aron ditinjau dari dimensi kompetensi teknis dengan persentase tertinggi sebesar $88,02 \%$, hal ini dikarenakan para petugas Gancang Aron selalu berpenampilan rapi dalam memberikan pelayanan, sedangkan persentase terendah sebesar $85,75 \%$.

Skor Tingkat Kepuasan Pasien Pengguna Program Gancang Aron Ditinjau dari Dimensi Akses Terhadap Pelayanan 
Dimensi akses terhadap pelayanan mengandung makna bahwa pelayanan kesehatan tidak terhambat oleh keadaan

Tabel 4. Rata-rata Tingkat Kepuasan Pasien Pengguna Program Gancang Aron Berdasarkan Dimensi Akses Terhadap Pelayanan ekonomi, geografis, sosial dan budaya, organisasi, ataupun bahasa (Wanarto, 2013).

\begin{tabular}{llcccc}
\hline No. & \multicolumn{1}{c}{ Pernyataan } & Kinerja & Kepentingan & Nilai Kepuasan & Kategori \\
\hline 1. & $\begin{array}{l}\text { Prosedur pelayanan Gancang } \\
\text { Aron mudah }\end{array}$ & 3,27 & 3,72 & $87,90 \%$ & Sangat puas \\
2. $\begin{array}{l}\text { Biaya pengantaran obat } \\
\text { terjangkau }\end{array}$ & 3,31 & 3,64 & $90,93 \%$ & Sangat puas \\
$\begin{array}{l}\text { 3. } \\
\begin{array}{l}\text { Petugas berperilaku adil (tanpa } \\
\text { membeda-bedakan status sosial, } \\
\text { bahasa, dan budaya) dalam } \\
\text { melayani pasien }\end{array}\end{array}$ & 3,13 & 3,66 & $85,52 \%$ & Sangat puas \\
$\begin{array}{l}\text { Petugas menyampaikan informasi } \\
\text { dengan bahasa yang mudah } \\
\text { dipahami oleh pasien }\end{array}$ & 3,17 & 3,74 & $84,76 \%$ & Sangat puas \\
\hline \multicolumn{1}{c}{ Rata-rata } & 3,22 & 3,69 & $87,28 \%$ & Sangat puas \\
\hline
\end{tabular}

Berdasarkan hasil penelitian yang disajikan dalam tabel 4 menunjukkan bahwa tingkat kepuasan pasien pengguna program Gancang Aron ditinjau dari dimensi akses terhadap pelayanan dengan persentase tertinggi sebesar 90,03\%, hal ini dikarenakan biaya pengantaran obat oleh gojek terjangkau, sedangkan persentase terendah sebesar $84,76 \%$. Komunikasi antara petugas dengan pasien merupakan suatu hal yang sangat penting namun sering terabaikan dalam pelaksanaan pelayanan kesehatan (Royanah, 2015). Padahal komunikasi yang baik bisa mempengaruhi berbagai aspek, termasuk

Tabel 5. Rata-rata Tingkat Kepuasan Pasien Pengguna Program Gancang Aron Berdasarkan Dimensi Efektivitas

\begin{tabular}{cccccc}
\hline No. & \multicolumn{1}{c}{ Pernyataan } & Kinerja & Kepentingan & Nilai Kepuasan & \multicolumn{1}{c}{ Kategori } \\
\hline 1. & $\begin{array}{l}\text { Pelayanan program Gancang } \\
\text { Aron mampu mengatasi keluhan } \\
\text { terhadap waktu tunggu obat }\end{array}$ & 3,15 & 3,68 & $85,60 \%$ & Sangat puas \\
$\begin{array}{l}\text { Petugas tepat waktu dalam } \\
\text { melayani pasien }\end{array}$ & 2,99 & 3,80 & $78,68 \%$ & Puas \\
\hline Rata-rata & 3,07 & 3,74 & $82,14 \%$ & Sangat Puas \\
\hline
\end{tabular}

Berdasarkan hasil penelitian yang disajikan dalam tabel 5 menunjukkan bahwa tingkat kepuasan pasien pengguna program Gancang Aron ditinjau dari dimensi efektivitas dengan persentase tertinggi sebesar $85,60 \%$. hal ini dikarenakan pelayanan program Gancang Aron mampu mengatasi keluhan pasien terhadap waktu tunggu obat. Sedangkan kepuasan pasien. Penggunaan bahasa yang digunakan oleh petugas untuk berkomunikasi dengan pasien pengguna program Gancang Aron adalah bahasa Indonesia.

\section{Skor Tingkat Kepuasan Pasien Pengguna Program Gancang Aron Ditinjau dari Dimensi Efektivitas}

Mutu pelayanan kesehatan tergantung pada efektivitas yang mencakup norma pelayanan kesehatan dan petunjuk klinis sesuai standar yang ada (Royanah, 2015). 
ini sejalan dengan pendapat Kelmanutu yang mengemukakan bahwa agar layanan dapat memuaskan konsumen yang diberikan pelayanan, maka waktu pelayanannya harus tepat (Kelmanutu, 2013).

\section{Skor Tingkat Kepuasan Pasien Pengguna Program Gancang Aron Ditinjau dari Dimensi Hubungan antar Manusia}

Dimensi hubungan antar manusia berkaitan dengan interaksi antara petugas dengan petugas dan petugas dengan pasien/ masyarakat (Royanah, 2015). Berikut ini disajikan tabel rata-rata tingkat kepuasan pasien pengguna program gancang aron berdasarkan dimensi hubungan antar manusia seperti yang tersaji pada tabel 6 .

Tabel 6. Rata-rata Tingkat Kepuasan Pasien Pengguna Program Gancang Aron Berdasarkan Dimensi Hubungan Antar Manusia

\begin{tabular}{|c|c|c|c|c|c|}
\hline No. & Pernyataan & Kinerja & Kepentingan & Nilai Kepuasan & Kategori \\
\hline 1. & $\begin{array}{l}\text { Petugas melayani pasien dengan } \\
\text { ramah, sabar, dan sopan }\end{array}$ & 3,21 & 3,76 & $85,37 \%$ & Sangat puas \\
\hline 2. & $\begin{array}{l}\text { Petugas menerima dan } \\
\text { mendengarkan keluhan pasien } \\
\text { dengan baik }\end{array}$ & 3,07 & 3,84 & $79,95 \%$ & Puas \\
\hline 3. & $\begin{array}{l}\text { Petugas menjawab dengan baik } \\
\text { pertanyaan pasien }\end{array}$ & 3,05 & 3,70 & $82,43 \%$ & Sangat puas \\
\hline 4. & $\begin{array}{l}\text { Petugas tanggap terhadap keluhan } \\
\text { pasien }\end{array}$ & 3,09 & 3,74 & $82,62 \%$ & Sangat puas \\
\hline & Rata-rata & 3,11 & 3,76 & $82,59 \%$ & Sangat puas \\
\hline
\end{tabular}

Berdasarkan hasil penelitian yang disajikan dalam tabel 6 menunjukkan bahwa tingkat kepuasan pasien pengguna program Gancang Aron ditinjau dari dimensi hubungan antar manusia dengan persentase tertinggi sebesar 85,37\%, hal ini dikarenakan petugas selalu melayani dengan ramah, sabar, dan sopan. Sedangkan persentase terendah sebesar 79,95\%. Menurut hasil penelitian Tandya dalam (Kelmanutu, 2013), faktor perhatian personal bisa memberi kontribusi yang besar pengaruhnya dalam meningkatkan loyalitas pasien. Sehingga, faktor perhatian personal memegang peranan penting dalam mencapai kepuasan pasien (Kelmanutu, 2013).

\section{Skor Tingkat Kepuasan Pasien Pengguna Program Gancang Aron Ditinjau dari Dimensi Efisiensi}

Efisiensi merupakan dimensi yang penting dari kualitas karena berpengaruh terhadap hasil pelayanan kesehatan apalagi umumnya kondisi sumber daya kesehatan terbatas (Royanah, 2015).

Tabel 7. Rata-rata tingkat kepuasan pasien pengguna program Gancang Aron berdasarkan dimensi efisiensi

\begin{tabular}{cccccc}
\hline No. & \multicolumn{1}{c}{ Pernyataan } & Kinerja & Kepentingan & Nilai Kepuasan & \multicolumn{1}{c}{ Kategori } \\
\hline 1. & $\begin{array}{l}\text { Petugas cepat dalam memberikan } \\
\text { pelayanan program Gancang Aron }\end{array}$ & 3,03 & 3,59 & $84,40 \%$ & Sangat puas \\
2. & $\begin{array}{l}\text { Instalasi farmasi memiliki } \\
\text { persediaan obat yang lengkap }\end{array}$ & 3,11 & 3,90 & $79,74 \%$ & Puas \\
3. $\begin{array}{l}\text { Pengantaran obat dalam pelayanan } \\
\text { program Gancang Aron tidak } \\
\text { memerlukan waktu yang lama }\end{array}$ & 3,02 & 3,52 & $85,80 \%$ & Sangat puas \\
\hline & Rata-rata & 3,05 & 3,67 & $83,31 \%$ & Sangat puas \\
\hline
\end{tabular}

Berdasarkan hasil penelitian yang disajikan dalam tabel 7 menunjukkan bahwa tingkat kepuasan pasien pengguna program
Gancang Aron ditinjau dari dimensi efisiensi dengan persentase tertinggi sebesar $85,80 \%$, hal ini dikarenakan pengantaran obat dalam 
pelayanan program Gancang Aron tidak memerlukan waktu yang lama. Sedangkan persentase terendah sebesar $79,74 \%$, ini dikarenakan pasien merasa instalasi farmasi memiliki persediaan obat yang kurang lengkap, terkadang obat yang diresepkan tidak tersedia atau stok mengalami kekosongan di instalasi. Ketika hal ini terjadi, maka bagian pelayanan menghubungi bagian pengadaan untuk menanyakan apakah obat tersebut bisa di UP kan atau dibelikan di fasilitas kesehatan lain. Apabila ternyata obat tersebut tetap tidak bisa didapatkan, maka bagian pelayanan konfirmasi ke dokter apakah berkenan apabila obat tersebut diganti dengan obat lain yang memiliki fungsi sama. Fasilitas kesehatan lain dalam hal ini yaitu rumah sakit lain atau apotek lain, diantaranya Rumah Sakit Yasmin, Rumah Sakit Fatimah, apotek nalendra, dan sebagainya. Sedangkan apabila obat tersebut tidak masuk formularium dan/atau pasien tersebut adalah pasien umum, maka petugas mengcopy resepnya dan pasien membeli sendiri obat di luar.

\section{Skor Tingkat Kepuasan Pasien Pengguna Program Gancang Aron Ditinjau dari Dimensi Kelangsungan Pelayanan}

Kelangsungan pelayanan artinya pasien memperoleh layanan secara utuh sesuai dengan keperluan (Bustami, 2011).

Tabel 8. Rata-rata Tingkat Kepuasan Pasien Pengguna Program Gancang Aron Berdasarkan Dimensi Kelangsungan Pelayanan

\begin{tabular}{clcccc}
\hline No. & \multicolumn{1}{c}{ Pernyataan } & Kinerja & Kepentingan & Nilai Kepuasan & Kategori \\
\hline 1. & Tidak terjadi keterlambatan dalam & 3,35 & 3,52 & $95,17 \%$ & Sangat puas \\
& $\begin{array}{l}\text { pengantaran obat kepada pasien } \\
\text { 2. }\end{array}$ & & & & \\
Petugas mencatat data pasien & 3,11 & 3,60 & $86,39 \%$ & Sangat puas \\
3. Pasien mendapatkan pelayanan sesuai & 3,27 & 3,62 & $90,33 \%$ & Sangat puas \\
\hline & & & & \\
\hline & Rengan kebutuhan & 3,24 & 3,58 & $90,63 \%$ & Sangat puas \\
\hline
\end{tabular}

Berdasarkan hasil penelitian yang disajikan dalam tabel 8 menunjukkan bahwa tingkat kepuasan pasien pengguna program Gancang Aron ditinjau dari dimensi kelangsungan pelayanan dengan persentase tertinggi sebesar $95,17 \%$, hal ini dikarenakan tidak terjadi keterlambatan dalam pengantaran obat kepada pasien. Sedangkan persentase terendah sebesar $86,39 \%$.

\section{Skor Tingkat Kepuasan Pasien Pengguna Program Gancang Aron Ditinjau dari Dimensi Keamanan}

Keamanan berarti meminimalkan
resiko cedera, infeksi, efek samping, ataupun bahaya lain yang berhubungan dengan pelayanan. Segala hal yang dilaksanakan di tempat layanan harus aman dari kemungkinan terjadinya bahaya (Bustami, 2011). Keputusan Menteri Pemberdayaan Aparatur Negara Nomor KEP/25/M.PAN/2004 menyebutkan, keamanan pelayanan ialah terjaminnya tingkat keamanan lingkungan unit penyelenggara pelayanan ataupun sarana yang digunakan, sehingga masyarakat merasa tenang untuk mendapatkan pelayanan terhadap resikoresiko yang diakibatkan dari pelaksanaan pelayanan.

Tabel 9. Rata-rata Tingkat Kepuasan Pasien Pengguna Program Gancang Aron Berdasarkan Dimensi Keamanan

\begin{tabular}{cccccc}
\hline No. & \multicolumn{1}{c}{ Pernyataan } & Kinerja & Kepentingan & Nilai Kepuasan & Kategori \\
\hline 1. & $\begin{array}{l}\text { Petugas memberikan petunjuk cara } \\
\text { minum obat }\end{array}$ & 3,10 & 3,61 & $85,87 \%$ & Sangat puas \\
2. & $\begin{array}{l}\text { Obat terbungkus rapat dan diterima } \\
\text { dalam kondisi baik }\end{array}$ & 3,26 & 3,72 & $87,63 \%$ & Sangat puas \\
3. & Petugas menjelaskan tentang dosis, & 3,02 & 3,62 & $83,43 \%$ & Sangat puas
\end{tabular}

kegunaan, cara penyimpanan, dan

efek samping obat secara tepat 
4. Obat yang diterima pasien sesuai dengan yang ada di resep
3,30 3,17
3,77

3,68

$87,53 \%$ $86,12 \%$
Sangat puas

Sangat puas

Berdasarkan hasil penelitian yang disajikan dalam tabel 9 menunjukkan bahwa rata-rata tingkat kepuasan pasien pengguna program Gancang Aron ditinjau dari dimensi keamanan adalah $86,12 \%$ dengan kategori sangat puas. Persentase tertinggi tingkat kepuasan sebesar $87,63 \%$. Hal ini dikarenakan obat yang diantar oleh gojek ke rumah pasien selalu dalam keadaan terbungkus rapat dan diterima pasien dalam kondisi baik yakni tidak kadaluarsa dan tidak rusak ataupun bocor. Sedangkan persentase terendah sebesar $83,43 \%$ dengan kategori sangat puas.

\section{Skor Tingkat Kepuasan Pasien Pengguna Program Gancang Aron Ditinjau dari Dimensi Kenyamanan}

Fasilitas, tampilan fisik tempat layanan, kebersihan, peralatan medis dan nonmedis berhubungan dengan dimensi kenyamanan Kenyamanan merupakan dimensi mutu yang tidak berkaitan langsung dengan efektivitas klinis, namun berpengaruh pada kepuasan pasien dan keputusan pasien untuk kembali mengakses pelayanan kesehatan. Kenyamanan ialah aspek penting untuk mengurangi rasa jenuh pasien saat menunggu giliran (Bustami, 2011).

Tabel 10. Rata-rata Tingkat Kepuasan Pasien Pengguna Program Gancang Aron Berdasarkan Dimensi Kenyamanan

\begin{tabular}{cccccc}
\hline No. & \multicolumn{1}{c}{ Pernyataan } & Kinerja & Kepentingan & Nilai Kepuasan & \multicolumn{1}{c}{ Kategori } \\
\hline 1. & Kondisi depo farmasi delivery & 3,11 & 3,76 & $82,71 \%$ & Sangat puas \\
Gancang Aron bersih & 2,82 & 3,72 & $75,81 \%$ & Puas \\
2. & Ruang tunggu memadai & 2,59 & 3,42 & $75,73 \%$ & Puas \\
3. & $\begin{array}{l}\text { Tersedianya AC/televisi/majalah di } \\
\text { ruang tunggu }\end{array}$ & 3,11 & 3,76 & $82,71 \%$ & Sangat puas \\
$\begin{array}{l}\text { Kondisi depo farmasi delivery } \\
\text { Gancang Aron bersih }\end{array}$ & 2,89 & 3,64 & $79,33 \%$ & Puas \\
\hline$\quad$ Rata-rata & & & & \\
\hline
\end{tabular}

Berdasarkan hasil penelitian yang disajikan dalam tabel 10 menunjukkan bahwa tingkat kepuasan pasien pengguna program Gancang Aron ditinjau dari dimensi kenyamanan dengan persentase tertinggi sebesar 83,06\%, hal ini dikarenakan depo farmasi delivery Gancang Aron tertata rapi. Sedangkan persentase terendah sebesar $75,73 \%$, ini dikarenakan menurut pasien dalam ruang tunggu Gancang Aron kurang tersedia fasilitas seperti AC, televisi, dan majalah. Padahal tersedianya fasilitas seperti AC, televisi, dan majalah di ruang runggu akan membuat suasana ruang tunggu menjadi nyaman dan pasien tidak merasa bosan ketika harus mengantri untuk mendapatkan pelayanan.

Selain itu, menurut responden ruang tunggu pelayanan Gancang Aron kurang memadai. Hal ini dikarenakan ruang tunggu tersebut kurang luas dan tempat duduknya terbatas, sehingga ketika jumlah pasien yang datang banyak maka jumlah tempat duduk tidak mencukupi dan pasien harus berdiri untuk mengantri. Hal ini sejalan dengan penelitian yang dilakukan oleh (Yeni, 2017), bahwa adanya ketidakpuasan pasien terhadap tempat duduk ruang tunggu dapat disebabkan karena banyaknya jumlah pasien sehingga kursi tidak mencukupi dan pasien harus berdiri untuk mengantri.

\section{Diagram Kartesius}

Tingkat kepentingan dari kualitas pelayanan adalah seberapa penting suatu pelayanan yang diberikan rumah sakit bagi pasien terhadap kinerja pelayanan. Sedangkan tingkat kinerja merupakan hasil dari kualitas pelayanan yang diberikan 
RSUD Blambangan, yang dirasakan langsung oleh pasien pengguna program Gancang Aron. Gambar diagram kartesius tingkat kinerja dan tingkat kepentingan pelayanan program Gancang Aron di RSUD Blambangan, Kabupaten Banyuwangi di gambarkan pada gambar 1 berikut ini.

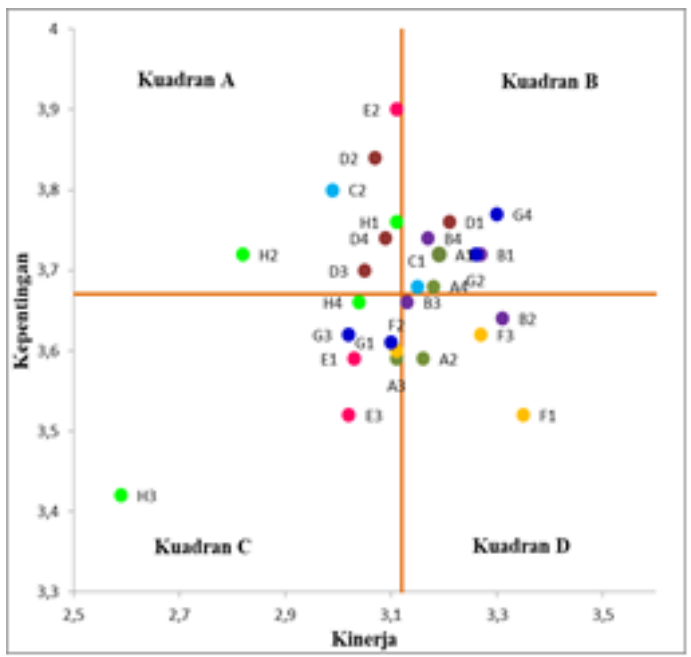

Gambar 1. Diagram Kartesius

Kuadran A ialah prioritas utama dimana atribut-atribut yang termasuk kuadran ini perlu diberikan perhatian lebih atau diperbaiki (Asfary, 2018). Hal ini dikarenakan atribut dalam kuadran A dianggap penting oleh pasien namun petugas Gancang Aron belum melaksanakan sesuai yang diharapkan pasien. Atribut pada kuadran ini memiliki tingkat kepentingan tinggi, namun tingkat kinerja rendah. Terdapat 7 atribut pada kuadran ini yaitu petugas tepat waktu dalam melayani pasien (C2), petugas menerima dan mendengarkan keluhan pasien dengan baik (D2), petugas menjawab dengan baik pertanyaan pasien (D3), petugas tanggap terhadap keluhan pasien (D4), instalasi farmasi memiliki persediaan obat yang lengkap (E2), kondisi depo farmasi delivery Gancang Aron bersih $(\mathrm{H} 1)$, dan ruang tunggu memadai $(\mathrm{H} 2)$.

Kuadran B ialah pertahankan prestasi, dimana pada kuadran ini memiliki tingkat skor yang paling tinggi baik dari segi tingkat kepentingan maupun tingkat kinerjanya, sehingga atribut yang berada pada kuadran B dapat dikatakan aman dan harus dipertahankan kinerjanya (Asfary, 2018). Hal ini dikarenakan umumnya tingkat pelaksanaannya telah sesuai dengan yang dibutuhkan dan diharapkan oleh pasien Gancang Aron (Syahfitriani et al.,
2020). Terdapat 8 atribut pada kuadran ini yaitu petugas terampil dalam melayani pasien (A1), kesesuaian etiket/label yang tertera pada obat dengan penjelasan petugas (A4), prosedur pelayanan Gancang Aron mudah (B1), petugas menyampaikan informasi dengan bahasa yang mudah dipahami oleh pasien (B4), pelayanan program Gancang Aron mampu mengatasi keluhan terhadap waktu tunggu obat (C1), petugas melayani pasien dengan ramah, sabar, dan sopan (D1), obat terbungkus rapat dan diterima pasien dalam kondisi baik (G2), dan obat yang diterima pasien sesuai dengan yang ada di resep (G4).

Kuadran $\mathrm{C}$ adalah prioritas rendah, dimana atribut ini dianggap kurang penting pengaruhnya bagi pasien dan kenyataannya kinerjanya tidak terlalu istimewa (Asfary, 2018). Atribut pada kuadran ini memiliki skor tingkat kepentingan dan tingkat kinerja yang rendah, namun atribut ini perlu diwaspadai karena tingkat kepentingan pasien dapat berubah seiring meningkatnya kebutuhan (Pratama, Hubeis and Pandjaitan, 2017). Terdapat 7 atribut pada kuadran ini yaitu pelaksanaan pelayanan program Gancang Aron sesuai dengan prosedur (A3), petugas cepat dalam memberikan pelayanan program Gancang Aron (E1), pengantaran obat dalam pelayanan program Gancang Aron tidak memerlukan waktu yang lama (E3), petugas mencatat data pasien (F2), petugas memberikan petunjuk cara minum obat (G1), petugas menjelaskan tentang dosis, kegunaan, cara penyimpanan, dan efek samping obat secara tepat (G3), serta tersedia AC/televisi/ majalah di ruang tunggu $(\mathrm{H} 3)$.

Kuadran D adalah berlebihan, dimana atribut pada kuadran ini dinilai memiliki tingkat kepentingan yang rendah namun tingkat kinerja yang diberikan tinggi. Dianggap kurang penting namun pelayanan yang diberikan sangat memuaskan (Asfary, 2018). Sehingga pasien menganggap bahwa pelayanan berlebihan. Terdapat 5 atribut pada kuadran ini yaitu petugas berpenampilan rapi (A2), biaya pengantaran obat terjangkau (B2), petugas berperilaku adil (tanpa membedakan status sosial, bahasa, dan budaya) dalam melayani pasien (B3), tidak terjadi keterlambatan dalam pengantaran obat kepada pasien (F1), dan pasien mendapatkan pelayanan sesuai dengan kebutuhan (F3). 


\section{KESIMPULAN DAN SARAN}

Berdasarkan hasil perhitungan skor kinerja dan skor kepentingan tiap atribut dalam dimensi mutu pelayanan, diketahui bahwa sebagian besar atribut dianggap penting namun kinerjanya masih ada yang dianggap kurang baik, yakni petugas kurang tepat waktu dalam melayani pasien, petugas kurang menerima dan mendengarkan keluhan pasien dengan baik, petugas menjawab dengan kurang baik pertanyaan pasien, petugas kurang tanggap terhadap keluhan pasien, instalasi farmasi memiliki persediaan obat yang kurang lengkap, kondisi depo farmasi delivery Gancang Aron kurang bersih, dan ruang tunggu kurang memadai. Tingkat kepuasan pasien pengguna program Gancang Aron ditinjau dari dimensi kompetensi teknis, akses terhadap pelayanan, efektivitas, hubungan antar manusia, kelangsungan pelayanan, efisiensi, dan keamanan adalah sangat puas. Namun, terdapat atribut yang belum memenuhi harapan pasien, yaitu petugas tepat waktu dalam melayani pasien, petugas menerima dan mendengarkan keluhan pasien dengan baik, instalasi farmasi memiliki persediaan obat yang lengkap, ruang tunggu memadai dan tersedianya AC/televisi/ majalah di ruang tunggu. Sedangkan, tingkat kepuasan pasien pengguna program Gancang Aron ditinjau dari dimensi keamanan adalah puas.

Saran yang dapat diberikan untuk RSUD Blambangan Kabupaten Banyuwangi adalah melakukan perbaikan terhadap atribut dalam kuadran A yang menjadi prioritas utama dalam upaya perbaikan dan peningkatan kualitas, yakni dengan cara: membuka pelayanan Gancang Aron lebih pagi, melakukan penambahan tempat duduk di ruang tunggu, serta melakukan perencanaan dan pengadaan obat yang lebih optimal. Selain itu, saran yang dapat diberikan yaitu melakukan penambahan tenaga apoteker Gancang Aron dan melakukan penyediaan aplikasi tersendiri untuk program Gancang Aron.

\section{REFERENSI}

Asfary, O. R. (2018). 'Analisis Kepuasan Pelanggan Menggunakan Pendekatan Importance Performance Analysis dan Customer Satisfaction Index (Studi Kasus pada Puskesmas Pakem
Yogyakarta)', Computers and Industrial Engineering, p.6.

Asmara, A. Y. and Rahayu, A. Y. S. (2019).

'Inovasi Pelayanan Kesehatan

Gancang Aron Di Kabupaten

Banyuwangi Dalam Perspektif Matrik Inovasi Sektor Publik', JPSI (Journal of Public Sector Innovations), 3(2), p.57. doi: 10.26740/jpsi.v3n2.p57-67.

Astuti and Kustiyah, E. (2014). 'Analisis Kepuasan terhadap Pasien Rawat Inap Atas Pelayanan Rumah Sakit Umum Kabupaten Sragen', Jurnal Gema, 26(48), pp. 1356-1371.

Bustami. (2011). Penjaminan Mutu Pelayanan Kesehatan \& Akseptabilitasnya. Jakarta: Erlangga.

Bustani, N. M., Rattu, A. J. and Saerang, J. S. M. (2015). 'Analisis Lama Waktu Tunggu Pelayanan Pasien Rawat Jalan di Balai Kesehatan Mata Masyarakat Propinsi Sulawesi Utara', Jurnal eBiomedik, 3(3). doi: 10.35790/ebm.3.3.2015.10456.

Esti et al. (2013). 'Pengaruh Waktu Tunggu dan Waktu Sentuh Pasien Terhadap Tingkat Kepuasan Pasien Poli Umum di Puskesmas Sukorame Kota Kediri', Journal of Chemical Information and Modeling, 53(9), pp. 1689-1699.

Gunawan, W. H. (2013). 'Analisis Pengaruh Kualitas Pelayanan Medis dan Pelayanan Administrasi Terhadap Loyalitas Pasien (Studi Pada Pasien Rawat Inap Rumah Sakit Pertamina Cirebon)', Skripsi, Fakultas Ekonomika dan Bisnis, Universitas Diponegoro.

Hastono, S. P. (2016). Analisa Data Pada Bidang Kesehatan. Jakarta: PT Raja Grafindo Perkasa.

Kelmanutu, L. (2013). 'Gambaran tentang Dimensi Mutu Pelayanan pada Unit Rawat Inap Rumah Sakit Umum Daerah Karel Sadsuitubun Langgur Kabupaten Maluku Tenggara Tahun 2013', Skripsi, Jurusan Manajemen Rumah Sakit, Fakultas Kesehatan Masyarakat, Universitas Hasanuddin.

Megawati, F. and Antari, N. P. U. (2017). 'Tingkat Kepuasan Pasien Terhadap Pelayanan Kefarmasian di Rumah Sakit Umum Daerah Klungkung 
Tahun 2016', Jurnal Ilmiah Medicamento, 3(2), pp. 115-119. doi: 10.36733/medicamento.v3i2.1035.

Mustika, D. and Sari, K. (2019). 'Kepuasan Pasien Terhadap Layanan Rawat Inap RSUD Jagakarsa Tahun 2017/2018', Jurnal Administrasi Rumah Sakit Indonesia, 5(3), pp. 147-152. Available at: http://journal.fkm.ui.ac.id/arsi/article/ view/2950.

Pasalli', A. and Patattan, A. A. (2021). 'Hubungan Mutu Pelayanan Kesehatan Dengan Kepuasan Pasien di Rumah Sakit Fatima Makale di Era New Normal', Jurnal Keperawatan Florence Nightingale, 4(1), pp. 1419. doi: $10.52774 / \mathrm{jkfn} . \mathrm{v} 4 \mathrm{i1} .57$.

Pratama, L., Hubeis, A. V. S. and Pandjaitan, N. H. (2017) 'Analisis Tingkat Kepuasan Anggota dan Strategi Pengembangan Koperasi (Studi Kasus Koperasi Kredit Sehati Jakarta)', Manajemen IKM: Jurnal Manajemen Pengembangan Industri Kecil Menengah, 12(1), p. 104. doi: 10.29244/mikm.12.1.104-115.

Rivaldi, M. P., Syahril, E. and Matto, R. (2019). 'Analisis Tingkat Kepuasan Pelayanan Pasien Rawat Inap di Rumah Sakit Ibnu Sina Makassar Tahun 2018', UMI Medical Journal, 4(1), pp. 12-30. doi: 10.33096/umj.v4i1.48.

Royanah, U. (2015). Jaminan Kesehatan Nasional Bukan Penerima Bantuan Iuran (Non PBI) di Puskesmas Halmahera Kota Semarang Tahun 2015, Skripsi, Program Studi Ilmu Kesehatan Masyarakat, Fakultas Ilmu Keolahragaan, Universitas Negeri Semarang.

Sesrianty, V., Machmud, R. and Yeni, F. (2019). 'Analisa Kepuasan Pasien Terhadap Mutu Pelayanan Keperawatan', 6(2), pp. 116-126.

Sugiyono. (2015). Metode Penelitian Kuantitatif, Kualitatif, dan $R \& D$. Bandung: Alfabeta.

Supartiningsih, S. (2017). 'Kualitas Pelayanan dan Kepuasan Pasien Rumah Sakit: Kasus Pada Pasien
Rawat Jalan', Jurnal Medicoeticolegal dan Manajemen Rumah Sakit 10.18196/jmmr.2016, 6(1), pp. 9-15. doi: 10.18196/jmmr.6122.

Suratri, Suryati, and Edwin. (2018). 'Kepuasan Pasien terhadap Kualitas Pelayanan Pasien Rawat Jalan Rumah Sakit di 7 Provinsi di Indonesia', Buletin Penelitian Kesehatan, 46(4), pp. 239-246. doi: 10.22435/bpk.v46i4.33.

Syahfitriani et al. (2020). 'Analisis Tingkat Kepuasan Pasien Terhadap Kualitas Pelayanan Perawat', 5(2), pp. 149157.

Ujiati, U., Majid, R. and Rasma, R. (2017). 'Analisis Kepuasan Pasien Pada Layanan Rawat Jalan Berdasarkan Metode Importance Performance Analisys (IPA) di Puskesmas BenuBenua Tahun 2016', Jurnal Ilmiah Mahasiswa Kesehatan Masyarakat Unsyiah, 2(6), p. 198186. doi: $10.37887 /$ jimkesmas.

Wanarto, G. . (2013). Penilaian Mutu Pelayanan Kesehatan oleh Pelanggan. Magetan: Forum Ilmiah Kesehatan (Forikes).

Widyanti, R. N. (2018). 'Gambaran Program Gancang Aron di Instalasi Farmasi Rumah Sakit Umum Daerah Blambangan Kabupaten Banyuwangi', Digital Repository Universitas Jember, (September 2019), pp. 1-101.

Winarno, H. and Absror, T. (2017). 'Analisis Kualitas Pelayanan dengan Metode Service Quality (Servqual) dan Importance Performance Analysis (IPA) pada PT. Media Purna Engineering', Jurnal Manajemen Industri dan Logistik, 1(2), pp. 67-79.

Yeni, I. and Budi, S. C. (2017) 'Kepuasan Pasien TNI Terhadap Pelayanan Pendaftaran Rawat Jalan Dengan Metode Importance Performance Analysis (IPA) di RSPAU Dr. S. Hardjolukito', Jurnal Kesehatan Vokasional, 1(2), p. 53. doi: 10.22146/jkesvo.27570. 